Piotr BIELACZYC

\title{
An overview of particle number emission from direct injection SI engine in scope of new legislation rules
}

\begin{abstract}
The main advantages of using direct injection in an SI engine, such as lower fuel consumption and higher thermal efficiency, implicate a new problem concerning gasoline engines: the emission of particulate matter. The observed issue has been a significant direction of development of the contemporary DISI engine over the last decade. This paper contains an overview of the results of PN emission, which were obtained from experiments conducted at BOSMAL and from the literature. Current and future legal regulations regarding PN emissions were collated to the test results.
\end{abstract}

Key words: particle number PN; direct injection SI engine; legislation rules; size distribution; light duty vehicles

\section{Analiza emisji liczbowej cząstek stałych z silników z zapłonem iskrowym i bezpośrednim wtryskiem benzyny w świetle nowych przepisów prawnych}

\begin{abstract}
Główne korzyści z zastosowania bezpośredniego wtrysku benzyny w silnikach ZI, takie jak mniejsze zużycie paliwa czy większa sprawność termiczna silnika, wiaża się także z problemem niespotykanym dotad w silnikach ZI, tj. z emisja cząstek statych. Przez ostatnia dekadę zjawisko to wyznaczyło kierunek rozwoju współczesnych silników benzynowych z bezpośrednim wtryskiem. Artykut ten zawiera przegląd wyników badań emisji liczby cząstek statych w trakcie różnych projektów badawczych zrealizowanych w Instytucie BOSMAL, a także przedstawionych w literaturze. Wyniki odniesiono do obecnych i przyszłych wymogów prawnych dotyczacych emisji cząstek stałych.

Słowa kluczowe: liczba czastek statych, silnik ZI z bezpośrednim wtryskiem, przepisy prawne, rozkład czastek statych, lekkie pojazdy samochodowe
\end{abstract}

\section{Introduction}

Particulate emissions seem to be one of the biggest threats of the modern world. They are the subject of a significant number of investigations. Scientists are trying to answer the most important questions regarding particulates' influence on human health and the environment. As is known, particles are chemically inert, but they are vectors for carcinogenic compounds. Due to those observations, the most significant for human health are the smallest particles, of dimension below $2.5 \mu \mathrm{m}$.

Combustion engines are said to be the main source of particles in the automotive industry. In previous years it was thought that only compression ignition engines emitted particulate matter. Nowadays, because of the advancement of direct injection SI engines, modern gasoline engines are also known as a PM source. Emission of Particle Mass (PM) and Number (PN) is an essential direction for the development of modern IC engines, both CI and SI. Global authorities are compiling new, stricter, emission standards, including the emission of PM and PN. Engine manufacturers, trying to fulfil those strict requirements, should introduce a number of solutions limiting the emission of particles.

\section{Particles in modern engines}

According to [27], particulate matter is defined as all substances other than unbound water, that are present in the exhaust gas in the solid (ash, carbon) or liquid phases. They are results of imperfect preparation of the fuel-air mixture,

\section{Wstęp}

Emisja cząstek stałych jest jednym z największych współczesnych zagrożeń dla środowiska. Naukowcy starają się odpowiedzieć na najważniejsze pytania dotyczące oddziaływania cząstek stałych na zdrowie ludzi i na środowisko. Jak wiadomo cząstki te są chemicznie obojętne, ale są nośnikami dla związków rakotwórczych. Z tego względu najbardziej istotne dla zdrowia człowieka są najmniejsze cząstki o wymiarach poniżej $2,5 \mu \mathrm{m}$.

Silniki spalinowe są uważane za główne źródło cząstek w przemyśle motoryzacyjnym. W poprzednich latach sądzono, że tylko silniki ZS emitują cząstki stałe. Obecnie, ze względu na popularyzację silników ZI z bezpośrednim wtryskiem, nowoczesne silniki benzynowe uznawane są również za źródło PM. Kwestie emisji masowej (PM) i liczby cząstek (PN) są istotne dla kierunków rozwoju nowoczesnych silników spalinowych zarówno ZS, jak i ZI. Rządy różnych państw opracowują obecnie nowe, ostrzejsze normy emisji, w tym i emisji PM oraz PN. Producenci silników, starając się spełnić te surowe wymagania, zmuszeni są wprowadzić wiele rozwiązań technicznych ograniczających emisję cząstek.

\section{Cząstki stałe w nowoczesnych silnikach spalinowych}

Według publikacji [27], cząstki stałe są zdefiniowane jako wszystkie substancje inne niż niezwiązana woda, które są obecne w gazach wylotowych w fazie stałej (popiół, węgiel) lub w fazie ciekłej. Są one wynikiem niedoskonałego przy- 
and in consequence, as a disturbance of combustion, both in CI and DISI engines. It is a very complex and wide issue, because particles reveal a wide variety of shape and dimensions. Chemical and physical properties cause difficulties in separating them into specific groups.

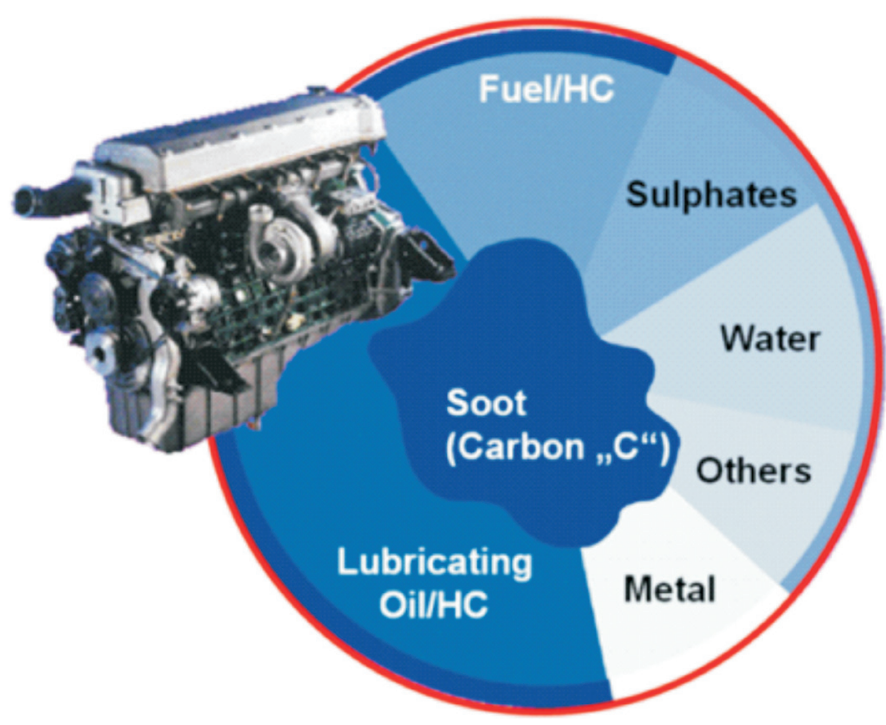

Fig. 1. Chemical profile of particulate matter (source: AVL) Rys. 1. Przykładowy skład chemiczny cząstki stałej

Particles structure consists of two fractions: the soluble organic fraction $\mathrm{PM}_{\mathrm{SOF}}$ and the insoluble fraction $\mathrm{PM}_{\mathrm{INSO}}$ [20]. In most cases, the structure is formed by a solid coil core and condensates of organic compounds (originating from the engine oil and the fuel), sulphur and nitrogen compounds [22]. Schemes of the chemical profile and structure of particulate matter are presented in Figures 1 and 2. The formation mechanism of particles in combustion engines uses a diffusion combustion model, in which precursors of soot are formed as a results of the thermal decomposition of hydrocarbons. As a consequence of coagulation and accumulation processes with other chemical compounds, this soot core grows into particulate matter.

Particles are divided by their size and origin. The first division incorporates four groups of particles [21]:

- TSP (Total Suspended PM) - ash in the range of $0.1-30 \mu \mathrm{m}$;

- $\mathrm{PM}_{10}$ - large particles of aerodynamic diameter $\left(\mathrm{D}_{\mathrm{P}}\right)$ below $10 \mu \mathrm{m}$;

- $\mathrm{PM}_{2.5}$ - small particles of DP below $2.5 \mu \mathrm{m}$;

- Nano- and ultra-particles - with $\mathrm{D}_{\mathrm{P}}$ below $50 \mathrm{~nm}$ and $100 \mathrm{~nm}$ respectively.

The origin-based division includes three groups [13]:

- ultrafine particles $\left(D_{\mathrm{P}}<100 \mathrm{~nm}\right)$ - also nanoparticles formed during the combustion and dilution, this group contains the largest number of particles,

- accumulation mode particles $\left(D_{\mathrm{P}} \leq 2.5 \mu \mathrm{m}\right)-$ formed through the agglomeration of ultrafine gotowania mieszanki paliwowo-powietrznej, a w związku z tym również zakłóconego procesu spalania zarówno w silnikach ZS, jak i DISI. Jest to bardzo skomplikowany i szeroki problem, gdyż cząstki tworzą się w różnorodnych kształtach i wymiarach. Ich właściwości chemiczne i fizyczne stwarzają trudności w rozdzieleniu ich na określone grupy.

Strukturę cząstek stanowią dwa typy związków: rozpuszczalne organiczne $\mathrm{PM}_{\mathrm{SOF}}$ (Particulate Matter Soluble Organic Fraction) oraz nierozpuszczalne $\mathrm{PM}_{\mathrm{INSOL}}$ (Particulate Matter Insoluble Organic Fraction) [20]. W większości ta struktura jest utworzona z litego rdzenia i warstwy kondensacji związków organicznych (pochodzących z oleju silnikowego i paliwa), siarki i związków azotu [22]. Skład chemiczny i strukturę cząstek przedstawiono na rysunkach 1 i 2 . Mechanizm powstawania cząstek w silnikach spalinowych obejmuje model spalania dyfuzyjnego, w którym prekursory sadzy powstają w wyniku rozkładu termicznego węglowodorów. W wyniku procesu krzepnięcia i akumulacji z innymi związkami chemicznymi, ten rdzeń sadzy staje się prekursorem powstawania cząstek stałych.

Cząstki stałe dzieli się ze względu na ich wielkość i źródło pochodzenia. Pierwszy podział obejmuje cztery grupy cząstek [21]:

- TSP (Total Suspended PM) - popiół w zakresie 0,1-30 $\mu \mathrm{m}$,

- $\mathrm{PM}_{10}$ - duże cząstki o średnicy aerodynamicznej (DP) poniżej $10 \mu \mathrm{m}$,

- $\mathrm{PM}_{2.5}$ - małe cząstki o średnicy DP poniżej 2,5 $\mu \mathrm{m}$,

- nanocząstki i ultradrobne cząstki - z DP odpowiednio poniżej $50 \mathrm{~nm}$ i $100 \mathrm{~nm}$.

Podział ze względu na pochodzenie obejmuje trzy grupy [13]:

- cząstki ultradrobne $\left(\mathrm{D}_{\mathrm{P}}<100 \mathrm{~nm}\right)$ - w tym również nanocząstki powstałe podczas procesu spalania i rozcieńczania; grupa ta zawiera największą liczbę cząstek,

- cząstki akumulacyjne $\left(\mathrm{D}_{\mathrm{p}} \leq 2,5 \mu \mathrm{m}\right)$ - utworzone przez aglomerację cząstek ultradrobnych, mogą zawierać warstwę skondensowanych lub zaabsorbowanych substancji lotnych,

- cząstki duże $\left(D_{\mathrm{P}} \leq 10 \mu \mathrm{m}\right)$ - utworzone przez proces

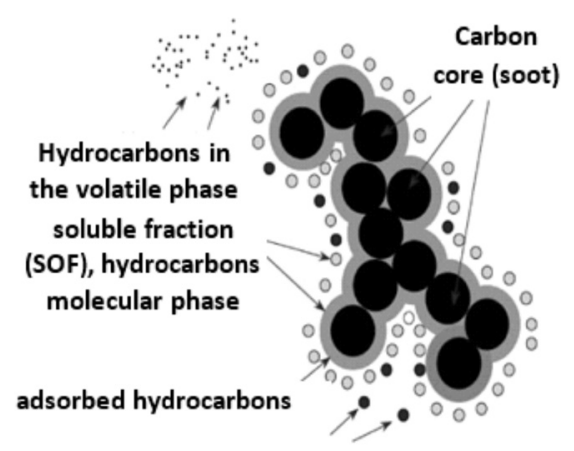

hydrated sulphate compounds

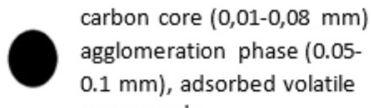
$0.1 \mathrm{~mm})$, adsorbed volatile compounds

adsorbed hydrocarbons

Condensed hydrocarbon particles

- hydrated sulphate compounds

Fig. 2. Structure of particulate matter [20, 22] Rys. 2. Struktura czastki statej 
particles, and may also contain a layer of condensed or absorbed volatile material,

- coarse mode particle $\left(D_{p} \leq 10 \mu \mathrm{m}\right)$ - formed as a result of accumulation and fusion with other particles; they are formed in the exhaust system.

The negative influence of the particles on human health depends on their diameter. It is thought that particulate matter below $10 \mu \mathrm{m}$ is a significant threat. The most dangerous compounds are adsorbed onto the surface of the PM as polycyclic aromatic hydrocarbons (PAH), sulphur compounds and metals.

Particles are said to cause cancer, but the most important effects of PM on human health are cardio and respiratory system diseases. Almost $90 \%$ of the EU's population is exposed to the negative influence of particulate matter [2].

\section{Direct injection spark ignition engines}

DISI engines have been introduced as an answer to demands for modern concepts of the ecological combustion engine of tomorrow. Current high technology PFI engines, although highly advanced, have nearly reached the limit of their potential as a system based on a throttle and port fuel injection (PFI) [27]. The main advantages of DISI engines, such as lower fuel consumption and higher thermal efficiency, are possible by using more complex injection system and a few control strategies. Those engines are able to work in two modes according to fuel distribution: homogeneous mode - a homogeneous mixture is formed in the cylinder; and stratified mode - a stratified mixture is formed in the cylinder, in such operating mode, the global $\lambda$ ratio has value greater than $1.3(\lambda \geq 1.3)$. Complicated control algorithms and complex fuel system force engineers to challenge a few obstacles in the field of emissions, combustion stability and control, fuel economy, performance and durability of the engine, and system complexity, which contains more complex emission control systems, sophisticated fuel and combustion systems. New control algorithms enforce a significantly increased number of calibration variables for system optimization [16].

The chemical structure of particulate matter emitted from DISI engines is comparable to PM emitted from CI engines. In stratified mode, PM is formed from organic carbon, soot and unburned and partially oxidised hydrocarbons. In homogeneous mode, the structure is simpler and contains mainly soot and volatile fractions as hydrocarbons [25]. The difference between emissions from DISI and CI engines is a higher share of volatile fractions and a variable share of the carbonaceous fractions. Particle structure is strongly dependent on engine operating parameters, such as engine load, engine mode, and as a result of the thermal state of the engine, the temperature and pressure in the cylinder [23]. What is more, particle morphology is strongly related to the type of fuel used to power the engine. Also, different fuels cause varying levels of emission [14].

The most important causes of particle formation in DISI engines are $[17,23,27]$ :

- in homogeneous mode $(\lambda=1.0)$ - wall-wetting, where drops of fuel are deposited on the cylinder surface, akumulacji oraz fuzji z innymi cząstkami; są wytwarzane w układzie wylotowym.

Negatywny wpływ cząstek na zdrowie człowieka zależy od ich średnicy. Uważa się, że cząstki poniżej 10 mikrometrów są istotnym zagrożeniem dla zdrowia ludzkiego. Związki najbardziej niebezpieczne są adsorbowane na powierzchni PM jako wielopierścieniowe węglowodory aromatyczne (PAH), związki siarki i metali.

Cząstki stałe są uznawane za rakotwórcze, ale najgroźniejsze skutki PM odnośnie do zdrowia człowieka to choroby układu oddechowego i krwionośnego. Prawie 90\% ludności UE jest narażona na negatywny wpływ cząstek stałych [2].

\section{Silniki benzynowe $z$ bezpośrednim wtryskiem paliwa}

Silniki DISI zostały wprowadzone jako zapotrzebowanie na nowoczesne rozwiązania ekologicznych silników spalinowych. Obecnie najnowsze silniki PFI, choć bardzo zaawansowane technologicznie, prawie osiągnęły szczyt ich potencjału jako systemu opartego na przepustnicy i wtrysku paliwa do kolektora dolotowego (PFI) [27]. Główne zalety silników DISI, takie jak mniejsze zużycie paliwa i większa wydajność cieplna, są możliwe przy zastosowaniu bardziej złożonego układu wtryskowego oraz kilku strategii sterowania. Silniki te mogą pracować w dwóch trybach, zgodnie z dystrybucją paliwa: tryb jednorodny - jednorodną mieszaninę formuje się w cylindrze, i tryb warstwowy - uwarstwioną mieszaninę formuje się w cylindrze; w tym trybie pracy ogólny współczynnik $\lambda$ ma wartość większą od 1,3 $(\lambda \geq 1,3)$. Skomplikowane algorytmy sterowania i złożone układy zasilania wymuszają na inżynierach wyzwania w zakresie emisji, stabilności i kontroli spalania, zużycia paliwa, wydajności i trwałości silnika oraz złożoności systemu. Nowe algorytmy sterowania wymuszają znacznie większą liczbę zmiennych kalibracyjnych do prawidłowej optymalizacji systemu [16].

Struktura chemiczna cząstek stałych emitowanych z silnika DISI jest porównywalna do PM emitowanych z silników ZS. W trybie warstwowym PM są tworzone z organicznego węgla, sadzy i niespalonych oraz częściowo utlenionych węglowodorów. W trybie jednorodnym budowa cząstek jest prostsza - zawierają one głównie sadzę i związki lotne [25]. Różnicą między emisją z silników ZS i z silników DISI jest większy udział składników lotnych i zmienny udział składników węglowych. Struktura cząstek bardzo zależy od parametrów pracy silnika, takich jak obciążenie silnika, tryb pracy silnika oraz, wynikających ze stanu cieplnego silnika, temperatury i ciśnienia w cylindrze [23]. Ponadto morfologia cząstek jest silnie związana z rodzajem paliwa stosowanego do zasilania silnika. Także różne paliwa mogą prowadzić do różnych poziomów emisji [14].

Najważniejszymi przyczynami powstawania cząstek stałych w silnikach DISI są [17, 23, 27]:

- w trybie jednorodnym $(\lambda=1,0)$ - skraplanie paliwa, gdzie krople paliwa osadzają się na powierzchni cylindra,

- w trybie warstwowym $(\lambda \geq 1,3)$ - niepełne spalanie 
- in stratified mode $(\lambda \geq 1.3)$ - the local area of rich fuel mixture and an incomplete combustion as a consequence,

- pool fires - the presence of a fine liquid fuel layer on the piston surface; in those areas the flame burn rate decreases and incomplete combustion occurs. The problem is characteristic for the wall-guided approach to create stratified charge [13];

- adequate evaporation of fuel - fuel drops are deposited on the cylinder surface and as a consequence there is a combustion disturbance, mostly during cold start of the engine. The problem is characteristic for spray-guided approach to create charge,

- fuel injection disturbance - the shape of the injected stream of fuel, poor atomization of fuel and incorrect time of injection,

- thermal condition of the engine - problems with cold start, achieving light-off temperature for the catalytic converter etc.,

- fuel properties - chemical structure, content of PAH, naphthalene and alkenes.

There are plenty of strategies to minimalize the process of particulate formation in the combustion chamber [23].

The first strategy comprises controlling the entire combustion process and engine operating conditions. First of all, the strategy includes ensuring the temperature of the combustion chamber is sufficient to provide the most complete process of combustion of the air-fuel mixture possible. The other way of preventing the emission of particulates is to minimize the oil layer in the combustion chamber. However, the most effective way of controlling the combustion process is to control the heating process of the engine after a cold start by using an intelligent cooling system. This solution has been used in many vehicle applications so far. Another strategy is focused on controlling the entire combustion process in order to ensure its optimum efficiency. The way to obtain that is to provide the optimum fuel mixture swirl, optimize fuel mixture motion intensity and prevent the formation rich mixture areas. Furthermore, applying and controlling the ignition delay can result in an increase of the exhaust gas temperature, which has a strong effect on the efficiency of the aftertreatment system (ATS). The third strategy aims to control air intake conditions. It can be realized by providing sufficient air volume, optimization of valve overlap, implementation of variable valve timing systems and optimization of the EGR system. Finally, formation of particulates is strongly connected with the fuel delivery process. That is why there is a strong need to implement optimized fuel injection models, minimize excessive wall wetting and improve the entire injection system by means of raising the injections pressures, providing high fuel temperature and applying multistaged injection patterns. In this context, some design innovations include hybrid injection systems combined through using direct and port fuel injection systems at the same time [23].

Implementation of those strategies at the same time may result in a synergistic effect, causing further decreases in particulate formation intensity. However, the process w wyniku powstawania lokalnych obszarów bogatej mieszanki paliwa,

- obecność cienkiej warstwy ciekłego paliwa na powierzchni tłoka - w tych obszarach prędkość spalania spada, co powoduje niecałkowite spalanie; problem ten jest charakterystyczny dla wtrysku paliwa typu wall-guided stosowanego do uzyskania uwarstwienia mieszanki [13],

- niewystarczające odparowanie paliwa-krople paliwa osadzają się na powierzchni cylindra, prowadząc w efekcie do zakłóceń procesu spalania, głównie podczas zimnego rozruchu silnika; problem ten jest charakterystyczny dla wtrysku paliwa typu spray-guided,

- zaburzenie wtrysku paliwa - kształt strumienia wtryskiwanego paliwa, słabe rozpylenie oraz niewłaściwy moment wtrysku dawki,

- stan cieplny silnika - problemy z zimnym rozruchem, osiągnięcie temperatury pracy reaktora katalitycznego itd.,

- właściwości paliwa - struktura chemiczna, zawartość WWA, naftalenu i alkenów.

Istnieje wiele strategii, aby zminimalizować proces powstawania cząstek w komorze spalania [23].

Pierwsza strategia zakłada kontrolę całego procesu spalania oraz warunków eksploatacji silnika. Przede wszystkim strategia ta zapewnia, że temperatura w komorze spalania jest wystarczająca, aby umożliwić najbardziej kompletny proces spalania mieszanki powietrzno-paliwowej. Innym sposobem zapobiegania emisji cząstek jest zminimalizowanie warstwy oleju w komorze spalania. Jednak najbardziej efektywnym sposobem sterowania procesem spalania jest kontrola procesu nagrzewania silnika, po zimnym rozruchu, za pomocą inteligentnego systemu chłodzenia. Rozwiązanie to zastosowano w wielu pojazdach.

Druga strategia skupia się na kontroli całego procesu spalania, w celu zapewnienia optymalnej wydajności. Uzyskuje się to dzięki zapewnieniu optymalnego zawirowania mieszanki paliwowej, optymalizacji prędkości ruchu mieszanki paliwowej i zapobieganiu tworzenia się obszarów o lokalnie bogatym składzie mieszanki. Ponadto zastosowanie i sterowanie opóźnieniem zapłonu może spowodować wzrost temperatury gazów spalinowych, który ma znaczący wpływ na sprawność systemu oczyszczania spalin (ATS).

Trzecia strategia ma na celu sterowanie warunkami dolotu powietrza. Może to być realizowane przez dostarczenie wystarczającej objętości powietrza, optymalizację przekrycia zaworów, wdrożenie systemu zmiennych faz rozrządu zaworów i optymalizacji systemu EGR. Ostatecznie proces powstawania cząstek stałych jest silnie powiązany $\mathrm{z}$ procesem dostarczania paliwa. Dlatego istnieje duże potrzeba wdrożenia optymalnych modeli wtrysku paliwa, zminimalizowania nadmiernego zwilżenia ścianek i poprawy całego układu wtrysku przez podniesienie ciśnienia wtryskiwanego paliwa, zapewnienie wysokiej temperatury paliwa i zastosowanie wielostopniowego wtrysku paliwa. W związku z tym niektóre innowacje konstrukcyjne to hybrydowe układy wtryskowe, obejmujące jednoczesną pracę bezpośredniego (DI) i pośredniego (PFI) systemu wtrysku paliwa [23]. 
of particulate formation cannot be avoided completely. In this context a crucial role is played by the aftertreatment system which reduces the mass and number of particulates. Improvements in the efficiency of the ATS can be achieved by assisting the processes of oxidation of the particulates in the exhaust manifold. It could be achieved by controlling the operational parameters of the engine, ensuring high exhaust temperatures and providing an appropriate quantity of oxygen. Quite a substantial factor is also the achievement of the light off point temperature (T50) in a relatively short period of time, which determines the catalyst efficiency [23].

The worst-case scenario assumes expanding the overall shape and complexity of the ATS by the addition of particulate filters. At present, compression ignition engines are commonly equipped with this kind of a solution. However, in the context of direct injection spark ignition engines there is a strong political and economic debate about the legitimacy and necessity of the introduction of the GPF technology. On the one hand, this solution would diminish the overall particulate emission to meaningless values, but on the other hand it is burdened with high costs of development and market introduction. For the time being, car makers have not decided ultimately whether to use GPFs or hold back [23].

In conclusion, there are many ways of diminishing the particulate emissions. Some of them are more effective than others. However, in the context of the future it's important to make a reasonable choice of using the most efficient and possibly the least expensive strategy - obviously from the consumer's point of view.

\section{Current and future emission limits for PM and PN}

Worldwide emission standards are becoming more and more rigorous in recent years. In most countries, PM emission is limited and over the years the maximum allowed level has become systematically lower [26]. In Europe, the maximum level of emissions presented as the Euro 5 standard is about $95 \%$ lower than the relevant level in the Euro 1 standard presented at the beginning of the 1990s [7].

In the USA, emission rules are divided into two groups. In all states, engine producers must fulfill the federal requirements presented by the EPA (US Federal Tier II). Additionally, in certain states such as California, additional requirements regarding the emissions must be met. In California, those additional rules are named CARB: LEV II/III and they are stricter than the federal rules. The group of states, where CARB became obligatory, is growing systematically. Both rules limit only the mass emission of particles (PM), whose level is related (among others) to the car mileage and car emission category [20, 25]. Emission limits for particulate matter in the USA are presented in Table 1 (see appendix 1).

In Europe, mandatory limits are named Euro 1-6. Increasingly more restrictive requirements are introduced to its measurement accuracy levels, and gravimetric measurements are no longer able to meet them [7]. In Euro 5a standard, for the first time, the emission of PM was also considered for
Jednoczesne wykorzystanie tych strategii może prowadzić do efektu synergicznego, powodując dalsze zmniejszenie natężenia wytwarzania cząstek. Jednak procesu formowania cząstek nie można całkowicie uniknąć. W tym kontekście kluczową rolę odgrywa system oczyszczania spalin, który zmniejsza masę i liczbę cząstek stałych. Poprawę skuteczności ATS można osiągnąć przez sprzyjanie procesom utleniania cząstek stałych w kolektorze wydechowym. Osiągnięcie tego jest możliwe dzięki regulacji parametrów pracy silnika, co zapewnia wysoką temperaturę spalin i dostarczenie odpowiedniej ilości tlenu. Znaczenie ma również osiągnięcie temperatury pracy (T50) w stosunkowo krótkim czasie, który określa wydajność katalizatora [23].

Najgorszy scenariusz zakłada rozszerzenie ogólnego kształtu i złożoności ATS przez dodanie filtrów cząstek stałych. Obecnie silniki wysokoprężne wyposażone są zazwyczaj w tego typu rozwiązania. Jednakże w odniesieniu do silników o zapłonie iskrowym z bezpośrednim wtryskiem wciąż toczy się debata w kontekście politycznym i gospodarczym o zasadności i konieczności wprowadzenia technologii filtrów GPF. Z jednej strony to rozwiązanie pozwoliłoby na zmniejszenie ogólnej emisji cząstek stałych do znikomych wartości, ale z drugiej strony jest obciążone wysokimi kosztami opracowywania i wprowadzenia na rynek. Na razie producenci samochodów nie zdecydowali ostatecznie, czy używać systemów GPF, czy pozostawać przy innych rozwiązaniach [23].

Podsumowując, istnieje wiele sposobów, o różnej skuteczności, zmniejszania emisji cząstek stałych. Jednak w kontekście przyszłości ważne jest, aby dokonać rozsądnego wyboru przy użyciu najbardziej skutecznej i możliwie najtańszej strategii -oczywiście z punktu widzenia konsumenta.

\section{Obecne i przyszłe limity emisji PM oraz PN}

Światowe normy emisji stają się w ostatnich latach coraz bardziej rygorystyczne. W większości krajów emisja PM jest ograniczona, a na przestrzeni ostatnich lat maksymalny dozwolony poziom stawał się coraz niższy [26]. W Europie maksymalny poziom emisji przedstawiony jako norma Euro 5 jest o 95\% niższy niż jej odpowiednik w standardzie Euro 1 wprowadzonym na początku 1990 roku [7].

W USA limity emisji są podzielone na dwie grupy. We wszystkich stanach producenci silników muszą spełniać wymogi federalne przedstawione przez EPA (US Federal Tier II). W niektórych stanach, np. w Kalifornii, muszą być spełnione dodatkowe wymogi dotyczące emisji. Nazwano je tu CARB: LEV II/III i są one bardziej rygorystyczne niż przepisy federalne. Grupa stanów, w których limit CARB jest obowiązkowy systematycznie wzrasta. Te obydwa limity prawne ograniczają emisję cząstek stałych tylko masowo (PM), a poziom jej jest związany, między innymi, z przebiegiem pojazdu i z jego klasą emisji [20, 25]. Dopuszczalne limity emisji cząstek stałych w USA są przedstawione w tabeli 1 (załącznik 1).

W Europie obowiązkowe limity emisji noszą nazwę Euro 1-6. Coraz bardziej restrykcyjne wymogi wprowadza się odnośnie do poziomu dokładności pomiaru testów 
DISI engines, with a limit of $5 \mathrm{mg} / \mathrm{km}$. Following standards (Euro 5b/6) introduced not only a reduction of particulate mass emission level, but also a limit for particulate number (PN) emissions. Starting in 2014, the Euro 6b standard introduced mandatory PN emission limit also for DISI engines. Engine producers are allowed a three year phase-in period, with a limit of $6 \times 10^{12} 1 / \mathrm{km}$. In 2017 , the new Euro $6 \mathrm{c}$ standard, will further decrease this limit to the level of $6 \times 10^{11} 1 / \mathrm{km}$. The Euro standards are presented in Table 2 (see appendix 2).

New standards also force changes in emission measurement equipment in modern exhaust emission laboratories. Despite the use of a climatic chamber for filter weighing, and a CVS tunnel, it is mandatory to use particulate counter. As an example, AVL's APC 489 fulfills those requirements. Exhaust gas is sampled from the CVS tunnel and diluted. Next, inside the evaporation tube, the gas is heated and the volatile emission components vaporize, leaving only solid particles. The gas is diluted once again and fed into the condensation particle counter (PNC), where butanol is condensed on the particles. Butanol enlarges the particles and as a result they become visually detectable. When the particles pass through the laser beam, they are counted by the scattered light pulses generated [29].

A modern emission laboratory for LDV is presented in figure A1 (see appendix) and in Figs 3 and 4. As an example, BOSMAL's Emission Laboratory was used.

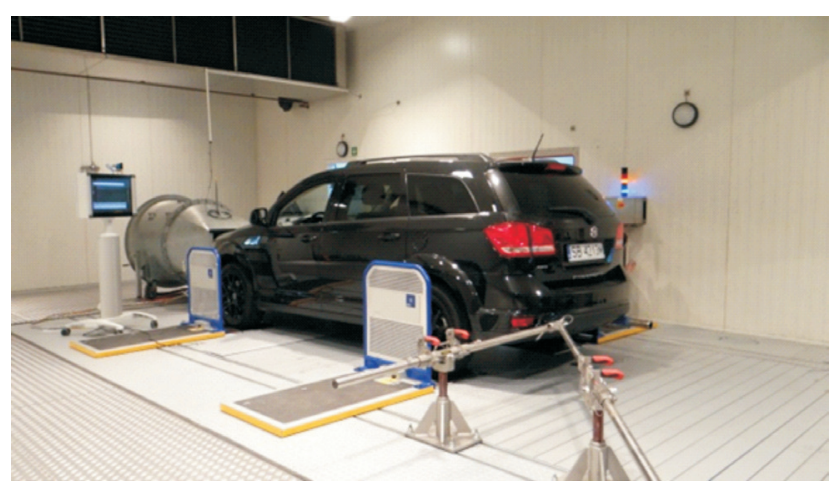

Fig. 3. Modern Emission Laboratory with 4WD chassis dyno Rys. 3. Współczesne laboratorium emisji z hamownia podwoziowa $4 \times 4$

\section{Overview of $P M$ and $P N$ emission results}

Plenty of cars with DISI engines were tested in BOSMAL Automotive Research and Development Institute's Emission Laboratory. Some of these results are presented in Figures 5 and 6 [7]. Both graphs present results from DISI, PFI and $\mathrm{CI}$ engines, and the limits of the latest Euro standards. The CI engine was fitted with a DPF. The test cycle was the NEDC. A description of the measurement methodology is presented in [6].

According to the results [7], the highest mass emission (PM) is characteristic for DISI engines in all phases of the NEDC test cycle. Significant differences between PFI and DISI engines are observed in the UDC phase, which include cold start. The thermal condition of the engine, ineffective operation of the catalytic converter and homogeneous charge emisji, stąd pomiary grawimetryczne nie są już w stanie im sprostać [7]. W standardzie Euro 5a po raz pierwszy ograniczono również emisję PM dla silników DISI, z limitem $5 \mathrm{mg} / \mathrm{km}$. Kolejne standardy (Euro 5b/6) wprowadziły nie tylko obniżenie poziomu emisji masowej cząstek, ale także ograniczenia emisji liczby cząstek (PN). Począwszy od 2014 roku obecny standard Euro $6 \mathrm{~b}$ wprowadził obowiązkowy limit emisji PN także dla silników DISI. Producenci silników mają trzy lata na wdrożenie odpowiedniej technologii w tym okresie obowiązuje ich limit $6 \times 10^{12} 1 / \mathrm{km}$. W roku 2017 nowy standard Euro $6 \mathrm{c}$ ma jeszcze bardziej zmniejszyć ten limit do poziomu $6 \times 10^{11} 1 / \mathrm{km}$. Normy Euro przedstawiono w tabeli 2 (załącznik 2).

Nowe standardy wymuszają również zmiany sprzętu do pomiaru emisji w nowoczesnych laboratoriach badań emisji spalin. Oprócz zastosowania komory klimatycznej do ważenia filtru cząstek i tunelu CVS należy obowiązkowo używać licznika cząstek. Przykładowo - AVL APC 489 spełnia te wymagania. Próbki spalin pobierane są z tunelu CVS i rozcieńczane. Następnie w przewodzie odparowania gaz ogrzewa się i lotne składniki emisji odparowują, pozostawiając tylko cząstki stałe. Gaz rozcieńcza się ponownie i wprowadza do kondensacyjnego licznika cząstek (PNC), gdzie na cząstkach stałych skrapla się butanol. Butanol powiększa rozmiar cząstek, w wyniku czego stają się one wykrywalne optycznie. Gdy cząstki przechodzą przez wiązki laserowe, zliczane są impulsy światła rozproszonego [29].

Nowoczesne laboratorium do badań emisji dla LDV przedstawiono na rysunku A1 (załącznik 3) oraz na rysunkach 3 i 4.
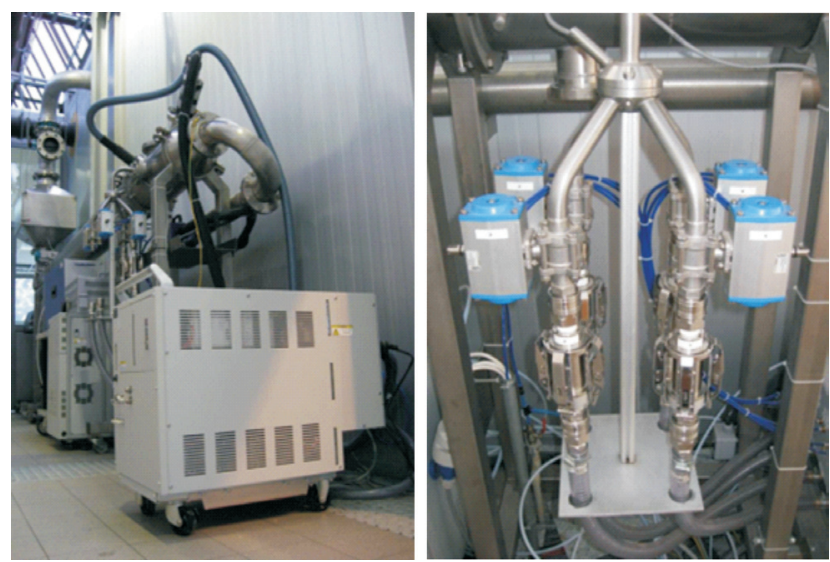

Fig. 4. Modern emission laboratory - emission measurement equipment Rys. 4. Wspótczesne laboratorium emisji-sprzęt do pomiaru emisji spalin

\section{Przegląd wyników badań emisji PM oraz PN}

W Instytucie Badań i Rozwoju Motoryzacji BOSMAL (Automotive Research and Development Institute) przebadano wiele samochodów z silnikami DISI. Wybrane wyniki badań przedstawiono na rysunkach 5 i 6 [7]. Oba rysunki przedstawiają wyniki dla silników DISI, PFI i silników ZS oraz limit obowiązujący dla najnowszych norm Euro. Silnik ZS był wyposażony w DPF. Pomiary przeprowadzono 


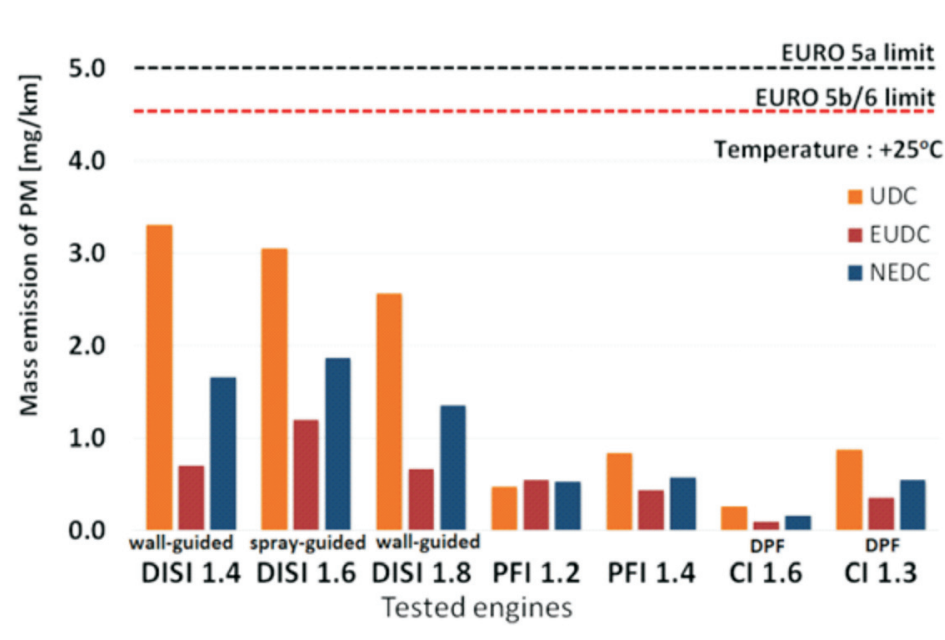

Fig. 5. Results of PM emission of various engines over the NEDC cycle [7] Rys. 5. Wyniki emisji PM dla różnych silników w teście NEDC [7] w cyklu NEDC. Opis metodologii pomiarów przedstawiono w pracy [6].

Analiza rysunków [7] wskazuje, że najwyższa emisja masowa (PM) jest charakterystyczna dla silników DISI we wszystkich fazach cyklu pomiarowego NEDC. Istotne różnice między silnikami PFI i DISI obserwowane są w fazie UDC, która obejmuje zimny rozruch. Stan cieplny silnika, niewydajna praca katalizatora i jednorodne rozłożenie ładunku są odpowiedzialne za zwiększenie powstawania PM. Należy zauważyć, że poziom emisji PM z silników DISI spełnia przyszłe wymagania normy Euro 6c.

Emisja PN dla wszystkich typów silników DISI jest duża i przekracza granicę emisji przyszłego standardu Euro 6c. Wyniki z całego testu NEDC przekraczają limit nowej normy europejskiej czterokrotnie. Limit mający obowiązywać podczas okresu wdrażania nowych limitów (standard Euro 6b) był spełniony dla wszystkich are responsible for greater PM formation. However, the level of PM emission from DISI engines meets the future Euro $6 \mathrm{c}$ requirements.

PN emission for all types of DISI engines is high and exceeds the future limit mandatory in the Euro $6 \mathrm{c}$ standard. The results from the entire NEDC are four times higher than the limits of the new European standard. The limit during the phase-in period (Euro 6b standard) was met for all engines. PN emission is presented in Fig. 6.

Test results shown in $[1,3,12,15,27]$ are similar to the results presented in [7]. In studies [1, 7, 12, 24], test results presents also measurement results of DISI engines in stratified mode. The PN emission is 50\% higher than the results for homogeneous mode and even 150\% higher compared to PFI engines [12].

An investigation $[1,26]$ separates the results of DISI engines into three groups, based on the construction of the combustion chamber:

- spray-guided - PM emission at $1.5 \mathrm{mg} / \mathrm{km} \mathrm{[26],} \mathrm{PN} \mathrm{and}$ PM emissions are very high at cold start; further during the test they decrease,

- wall-guided $-\mathrm{PN}$ emission at $1.9-2.1 \times 10^{12} 1 /$ $\mathrm{km}$ [26], during cold start, emission levels are low, but when considering the whole NEDC test results the levels are higher compared to the spray-guided type.

An important factor regarding PM and PN is the ambient temperature. In research $[7,8]$, an ambient temperature around $-7{ }^{\circ} \mathrm{C}$ caused higher emission of both of them. It is particularly noticeable during cold start and the UDC phase. In the UDC phase, PM emission was 6 times higher for this cold NEDC cycle, and PN emission was circa 2 times higher, compared to NEDC cycle performed at laboratory temperature $\left(\right.$ at $25^{\circ} \mathrm{C}$ ). Similar results are presented in $[6,19]$, despite the different measurement methodology in [19]. silników. Emisja PN jest przedstawiona na rysunku 6.

Wyniki badań przedstawione w pracach $[1,3,12,15$, 27] są podobne do wyników przedstawionych w publikacji [7]. W wynikach badań prac [1, 7, 12, 24] zawarto również wyniki pomiarów silników DISI w trybie warstwowym. Emisja PN jest o 50\% wyższa niż dla trybu jednorodnego, a nawet $150 \% \mathrm{w}$ porównaniu do silników PFI [12].

Wyniki badań silników DISI prace $[1,26]$ rozdzielają na trzy grupy - na podstawie konstrukcji komory spalania:

- wtrysk typu spray-guided - emisja PM na poziomie 1,5 $\mathrm{mg} / \mathrm{km}$ [26], emisje PN i PM są bardzo wysokie przy zimnym rozruchu, po czym maleją przy dalszej pracy;

- wtrysk typu wall-guided - emisja PN na poziomie $1,9-2,1 \times 10^{12} 1 / \mathrm{km}[26]$, poziom emisji niski przy zimnym rozruchu, ale w perspektywie całego testu NEDC poziom emisji jest wyższy niż dla wtrysku typu spray-guided.

Ważnym czynnikiem w zakresie emisji PM i PN jest temperatura otoczenia. W badaniach przedstawionych

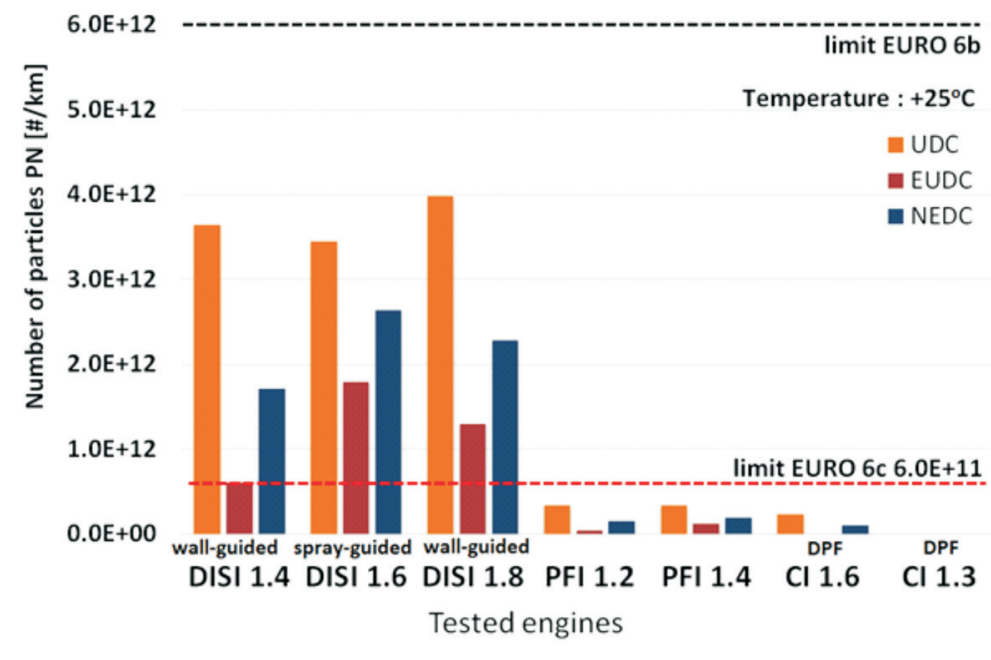

Fig. 6. Results of PN emission of various engines over the NEDC cycle [7]

Rys. 6. Wyniki emisji PN dla różnych silników w teście NEDC [7] 
In Figure 7, the size distribution from tests made during the NEDC cycle is presented. The research was performed at BOSMAL [7]. As measurement equipment, a TSI 3090 EEPS spectrometer was used, with the measurement range of 5.6-560 nm. A wide spectrum of PN emission is observed

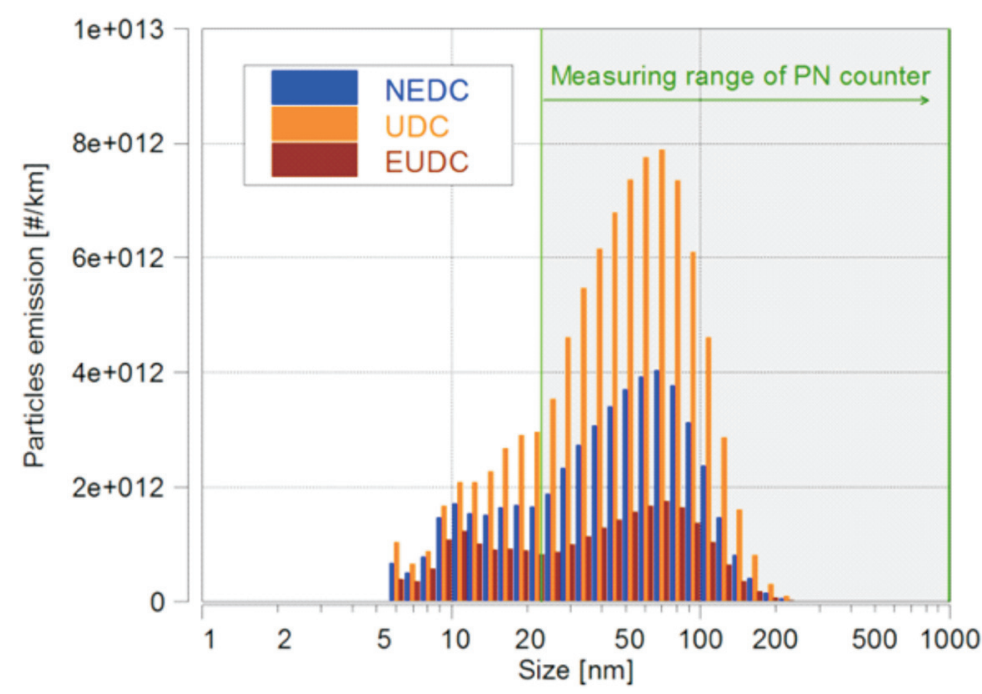

Fig. 7. Size distribution of PN during the NEDC cycle for DISI 1.4 litre engine [7] Rys. 7. Rozkład wielkości cząstek stałych podczas testu NEDC dla silnika 1.4 L DISI [7]

in the $\mathrm{D}_{\mathrm{p}}$ range of 5-200 $\mathrm{nm}$. Under cold conditions, during the UDC phase, accumulation mode particles are dominant. In the EUDC, the distribution is bimodal. The influence of temperature on size distribution is significant, and at lower temperatures, the concentration of accumulation mode particles is higher $[6,8]$. The PN measurement methodology is described in regulation EC 715/2007. According to this regulation, for $\mathrm{PN}$ detection the $\mathrm{PMP}-\mathrm{CPC}$ method should be used. CPC equipment has a narrow range $(23-2500 \mathrm{~nm})$ [4]. As shown in Fig. 7, particles with $\mathrm{D}_{\mathrm{P}}$ below $23 \mathrm{~nm}$ account for $20 \%$ of the PN emitted in the UDC phase and $37 \%$ of those emitted in the EUDC phase.

A PM and PN emission map is presented in the appendix. It is a summary of results presented in this paper. It shows emission levels for different configurations of emission cycles and various types of engine, fuel and ATS used during the tests. According to the results shown in Fig. A2, emission limits for PN described by the Euro $6 \mathrm{~b}$ standard are fulfilled by all DISI engines. The future Euro $6 \mathrm{c}$ standard is more problematic. Today's engines are not able to meet those requirements. The strategy of using ethanol for DISI engines is a promising solution to reduce emitted PM and PN $[9,10]$. Following research [18], usage of an E50 blend reduces the emission of PM by about $69 \%$ and for PN by about $52 \%$ in comparison to an E10 blend over the NEDC cycle. Usage of a GPF as a strategy to reduce both PM and PN, is a more complex issue. According to the results presented in Fig. A2, utilization of a GPF significantly reduces PN emission, which is comparable to the level for PFI engines. Unfortunately, this strategy is still in the development phase, due to economic w pracach $[7,8]$ temperatura otoczenia wynosiła około $-7^{\circ} \mathrm{C}$, co spowodowało wzrost emisji w obu przypadkach. Jest to szczególnie zauważalne podczas zimnego rozruchu silnika i fazy UDC. W fazie UDC emisja PM była 6 razy większa dla zimnego cyklu. Podobnie emisja PN była około 2 razy większa w porównaniu do cyklu NEDC przeprowadzonego $\mathrm{w}$ temperaturze laboratoryjnej $\left(25^{\circ} \mathrm{C}\right)$. Zbliżone wyniki przedstawiono w publikacjach [6, 19], pomimo odmiennej metodologii pomiarowej w pracy [19].

Na rysunku 7 przedstawiono rozkład wymiarowy cząstek uzyskany z testów wykonanych w cyklu NEDC. Badania przeprowadzono w Instytucie BOSMAL [7]. Do pomiarów był używany spektrometr TSI 3090 EEPS, działający W zakresie pomiarowym $5,6-560 \mathrm{~nm}$. W przedziale $\mathrm{D}_{\mathrm{p}}$ równym 5-200 nm zaobserwowano szeroki zakres emisji PN. Przy zimnym rozruchu, w fazie UDC, cząstki z trybu akumulacji są dominujące. W EUDC rozkład jest bimodalny. Wpływ temperatury na rozkład wielkości cząstek jest znaczny, a przy niższych temperaturach stężenie cząstek w trybie akumulacji jest wyższe [6, 8]. Metodologia pomiaru PN jest opisana w rozporządzeniu WE 715/2007. Zgodnie $\mathrm{z}$ tym rozporządzeniem do wykrywania $\mathrm{PN}$ należy stosować metodę PMP - CPC. Urządzenia CPC mają wąski zakres pomiarowy (23-2500 nm), [4]. Jak pokazano na rysunku 7 , cząstki o średnicy $\mathrm{D}_{\mathrm{P}}$ poniżej 23 odpowiadają za 20\% PN emitowanych w fazie UDC oraz za 37\% cząstek emitowanych w fazie EUDC.

Mapa emisji PM i PN została przedstawiona w załączniku 4 (rys. A2). Jest to podsumowanie wyników zaprezentowanych w niniejszym opracowaniu. Pokazuje ono poziomy emisji dla różnych konfiguracji cykli jezdnych i różnego rodzaju silnika, paliwa i ATS stosowanego podczas badań. Według wyników przedstawionych na rysunku A2 limity emisji dla PN podane przez normę Euro $6 \mathrm{~b}$ są spełnione przez wszystkie silniki DISI. Przyszły standard Euro 6c jest jednak większym problemem. Obecne silniki nie są w stanie spełnić tych wymagań. Strategia wykorzystania etanolu do silników DISI w celu zmniejszenia emisji PM i PN $[9,10]$ jest obiecującym rozwiązaniem. Zgodnie z wynikami badań podanymi w publikacji [18], wykorzystanie mieszanki paliwowej E50 redukuje emisję PM o około 69\%, a PN o około 52\% w stosunku do stosowania mieszanki E10 w cyklu NEDC. Wykorzystanie układu GPF jako strategii zmniejszenia zarówno emisji PM, jak i PN jest złożonym problemem. Zgodnie $\mathrm{z}$ wynikami przedstawionymi na rysunku A2, wykorzystanie GPF znacznie zmniejsza emisję $\mathrm{PN}$, do poziomu porównywalnego z poziomem dla silników PFI. Niestety, rozwiązanie to jest wciąż w fazie rozwoju, ze względu na problemy ekonomiczne i techniczne jego zastosowania. Szacowany koszt GPF wynosi 50-230 € [2]. Producenci biorą pod uwagę również aspekty techniczne, którymi są: rozmiar filtra, lokalizacja filtrów w ATS i struktura filtra. Parametry te są istotne do osiągnięcia celu. 
and technical aspects of its application. The estimated cost of a GPF is in the range of 50-230€ [2]. OEMs also consider the technical aspects, which are: filter size, filter location in the ATS and filter structure. Those parameters are significant to achieve the goal.

\section{Summary}

Particulate matter emissions have become more significant nowadays. In the past, it was though that only CI engines emitted the particles. Development of new DISI engines entail a completely new problem in spark ignition engines - particulate emission. Due to continuous development of internal combustion engines, both CI and SI, global authorities have introduced more strict and complex emission standards. In Europe, not only the particulate mass is limited, but also the number of particles which are emitted from both CI and DISI engines. The research results presented in the paper clearly show that modern engines meet current and future emission standards in terms of particulate mass emission. The main difficulty for OEMs is the future Euro $6 \mathrm{c}$ standard for DISI engines. SI engines with direct injection, which are commercially available today, do not meet the future requirements. Plenty of strategies have been developed by engine and vehicle manufacturers. Two of those strategies give promising results in PM and PN emission reduction:

1. Usage of ethanol blends as a fuel - this strategy could become the most interesting direction in the IC engine development $[9,10]$. E50 blends successfully reduce the $\mathrm{PM}$ and PN emission, and they are known also as an alternative fuel for future SI engines. The ethanol strategy is being tested around the world, with promising results.

2. Usage of a GPF - this strategy forces producers to equip cars with DISI engines with a particulate filter. Initial development projects have provided fantastic results, with reductions to the level of emissions for PFI engines. Unfortunately, this solution implicates a group of economic and technical problems, still to be solved.

Notably today's measurement methodology for PN presented in emission standards has very narrow range of measurement. The CPC (Condensation Particle Counter) methodology allows the measurement of particles of $D_{P}$ greater than $23 \mathrm{~nm}$. As the above analysis shows, a major group of particles, having a very negative influence on human health, are those of $\mathrm{D}_{\mathrm{p}}$ below $23 \mathrm{~nm}$. In consequence, there is a need to prepare a new measurement methodology in future emission standards, which will contain more fine solutions for particulate number measurement and also introduce size distribution as a mandatory survey.

\section{Podsumowanie}

Emisja cząstek stałych staje się obecnie coraz większym problemem w ochronie środowiska i zdrowia. W przeszłości tylko silniki ZS uważano za istotne źródło emisji cząstek. Rozwój nowych silników DISI stwarza nowy problem w silnikach z zapłonem iskrowym - emisję cząstek stałych. Ze względu na ciągły rozwój silników spalinowych, zarówno ZS, jak i ZI, wiele państw wprowadziło bardziej rygorystyczne i skomplikowane normy emisji. W Europie jest ograniczona nie tylko masa cząstek stałych, ale także liczba cząstek, które są emitowane z silników ZS i DISI. Wyniki badań przedstawione w tej pracy wyraźnie wskazują, że nowoczesne silniki spełniają obecne i przyszłe normy emisji spalin w zakresie emisji masy cząstek. Problemem dla producentów jest przyszły standard Euro 6c, mający obowiązywać dla silników DISI. Silniki ZI z bezpośrednim wtryskiem paliwa, które są dostępne na rynku już obecnie, nie spełniają przyszłych wymogów emisji. Producenci silników i pojazdów opracowali wiele strategii zmniejszania emisji. Dwie z tych strategii dają obiecujące wyniki w redukcji emisji PM i PN:

1. Zastosowanie mieszanki etanolu jako paliwa - może to stać się najbardziej interesującym kierunkiem rozwoju silników spalinowych [9, 10]. Mieszanki typu E50 skutecznie zmniejszają emisję PM i PN, i są również znane jako paliwa alternatywne dla przyszłych silników ZI. Możliwość wykorzystania etanolu jest testowana na całym świecie, z obiecującymi wynikami.

2. Wykorzystanie GPF; to rozwiązanie zmusza producentów do wyposażania samochodów z silnikiem DISI w filtry cząstek stałych. Wstępne projekty badawcze dostarczyły obiecujących rezultatów - zmniejszenie emisji cząstek do poziomu dla silników z wtryskiem typu PFI. Niestety, to rozwiązanie stwarza kilka problemów natury ekonomicznej i technicznej, które pozostają nierozwiązane.

Należy zauważyć, że obecna metoda pomiaru emisji PN ustalona przez normy europejskie ma bardzo wąski zakres pomiaru. Metodologia polegająca na użyciu CPC (Kondensacyjny Licznik Cząstek) umożliwia tylko pomiar cząstek o wartości $D_{\mathrm{P}}$ większej niż $23 \mathrm{~nm}$. Jak wynika z analizy przeprowadzonej w tej pracy, główna grupa cząsteczek, mająca bardzo negatywny wpływ na zdrowie ludzkie, to cząstki o $D_{\mathrm{p}}$ poniżej $23 \mathrm{~nm}$. W związku z tym istnieje potrzeba przygotowania nowej metodologii pomiaru dla przyszłych norm emisji, która może zawierać bardziej dokładne rozwiązania pomiaru liczby cząstek stałych, a także zawierać pomiar rozkładu wielkości cząstek jako obowiązkowego badania.

\section{Nomenclature/Skróty i oznaczenia}

ATS aftertreatment system/uktad oczyszczania spalin

CARB California Air Resources Board

CI compression ignition engine/silnik o zaptonie samoczynnym

CPC condensation particle counter/licznik cząstek stałych

CVS constant volume sampler/uktad o statym poborze próbki
DISI direct injection spark ignition/silnik benzynowy z wtryskiem bezpośrednim

EGR exhaust gas recirculation/uktad recyrkulacji spalin

EPA Environment Protection Agency/Agencja Ochrony Środowiska

FFV flexible fuel vehicle/pojazd wielopaliwowy 
SI spark ignition/silnik o zapłonie iskrowym

EU European Union/Unia Europejska

EUDC extra urban driving cycle/pozamiejski cykl jezdny

GPF gasoline particulate filter/filtr cząstek statych dla silników benzynowych

LDD light duty Diesel/silnik ZS dla pojazdu LDV

LDV light duty vehicle/lekki pojazd użtkowy

PFI port fuel injection/silnik z wtryskiem pośrednim do kolektora dolotowego

NEDC New European Driving Cycle/nowy europejski cykl jezdny
$\mathrm{PAH}$ polycyclic aromatic hydrocarbons/wielopierścieniowe węglowodory aromatyczne

PC passenger car/samochód osobowy

PM particulate matter/czastki state

PN particle number/liczba czastek statych

PNC particulate number counter/licznik czastek statych

TWC three-way-catalyst/reaktor katalityczny potrójnego działania

UDC urban driving cycle/miejski cykl jezdny

UE European Union/Unia Europejska

\section{Bibliography/Literatura}

[1] Andersson J., Keenan M., Akerman K. GDI particles - legislation, current levels and control. Ricardo Presentation, 9/99801.1, 2014

[2] Archer G. Particle emissions from petrol cars - briefing. Transport and Environment, 2013.

[3] Bielaczyc P. (ed.) Particulate matter emissions from engine and automobile sources. Workshop Proceedings form 1st Workshop on Particulate Matter Emissions from Engine and Automobile Sources, BOSMAL Automotive R\&D Institute, Bielsko-Biala 2012, Combustion Engines, 3 (150), 2012.

[4] Bielaczyc P., Czerwinski J., Woodburn J. Current trends in measurement and control of particle emissions from engines. Combustion Engines, 3 (150), 2012, 89-96.

[5] Bielaczyc P., Szczotka A., Woodburn J. Investigations on fuel ethanol content and ambient temperature on particle number and mass emissions from vehicles featuring direct injection gasoline engines. 16th ETH Conference on Combustion Generated Nanoparticles. Zurich 2012.

[6] Bielaczyc P., Szczotka A., Woodburn J. Particulate Emissions from European vehicles featuring direct injection spark ignition engines tested under laboratory conditions. SAE Technical Paper 2014-01-1608, 2014.

[7] Bielaczyc P., Szczotka A., Woodburn J. Particulate matter emissions from vehicles featuring direct injection spark ignition engines. FISITA 2014, F2014-CET-138.

[8] Bielaczyc P., Szczotka A., Woodburn J. The effect of a low ambient temperature on the cold-start emissions and fuel consumption of passenger cars. Proceedings of the Institution of Mechanical Engineers. Journal of Automobile Engineering, 225, 2011.

[9] Bielaczyc P., Szczotka A., Woodburn J. Regulated emissions, unregulated emissions and fuel consumption of two vehicles tested on various petrol-ethanol blends. SAE Technical Paper 2014-01-2824, 2014

[10] Bielaczyc P., Woodburn J., Klimkiewicz D., Pajdowski P., Szczotka A.. An examination of the effect of ethanol-gasoline blends' physicochemical propertieson emissions from a lightduty spark ignition engine. Fuel Processing Technology, 107, 2013, 50-63.

[11] Bischof C., Boger T., Gunasekaran N. Advanced particulate filter technologies for direct injection gasoline engine applications. CORNING Inc., DEER Conference, 16-19. 10. 2012.

[12] Braisher M., Stone R., Price P. Particle number emissions from a range of european vehicles. SAE Technical Paper 2010-010786, 2010.

[13] Eastwood P. Particulate emissions from vehicles. Wiley-Professional Engineering Publishing Series, 2008.
[14] Karavalakis G., Short D., Russell R., Jung H. et al. Assessing the impacts of ethanol and isobutanol on gaseous and particulate emissions from flexible fuel vehicles. Environmental Science \& Technology, 48, 2014, 14016-14024.

[15] Kazour J., Befrui B., Husted H., Raney M. et al. Innovative sprays and particulate reduction with GDi injectors. SAE Technical Paper 2014-01-1441, 2014.

[16] Khalek I., Bougher T., Jetter J. Particle emissions from a 2009 direct injection gasoline engines using different commercially available fuels. SAE International Journal of Fuels and Lubricatns, 3 (2), 2010, 623-637.

[17] Kittelson D., Kraft M. Particle formation and model in internal combustion engines. University of Cambridge. Preprint No. 142,2014 ,

[18] Kohler F. Testing of Particulate Emissions from Positive Ignition Vehicles with Direct injection. Transport and Environment 2013.

[19] Mamakos A., Martini G., Marotta A. Assessment of different technical options in reducing particle emissions from GDI vehicles. Journal of Aerosol Science, 63, 2013, 115-125.

[20] Merkisz J., Pielecha J. Emisja cząstek stałych ze źródeł motoryzacyjnych. Wyd. Politechniki Poznańskiej, Poznań 2014.

[21] Metz N. Health effects of diesel particulate matter - new investigations make the existence of a treshold value very probable. Aachener Kolloquim Fahrzeug und Motorentechnik, Aachen 2003

[22] Myung C., Park S. Exhaust nanoparticle emissions from internal combustion engines - review. International Journal of Automotive Technology,1 (13), 2012, 9-22.

[23] Piock W. et al. Strategies towards metting future particulate matter emissions requirements in homogeneous GDI engines. SAE Technical Paper 2011-01-1212, 2011.

[24] Storey J. et al. Exhaust particle characterization for lean and stoichiometric DI vehicles operating on ethanol-gasoline blends. SAE Technical Paper 2012-01-0437, 2012.

[25] Worldwide emissions standards: Passenger cars and light duty vehicles - guide book 2014-2015. Published by Delphi Corp. On-line access: www.delphi.com/emissions-pc

[26] Zhang S., McMahon W. Particulate emissions for LEV II light-duty gasoline direct injection vehicles. SAE International Journal of Fuels and Lubricants, 5 (2), 2012, 637-646.

[27] Zhao F., Harrington D., Lai M. Automotive gasoline direct injection engines. SAE International 2002.

[28] Zhao H. Advanced direct injection combustion engine technologies and development. Woodhead Publishing Limited, Vol. $1,2010$.

[29] AVL web site. On-line access: www.avl.com/emission-measurement 

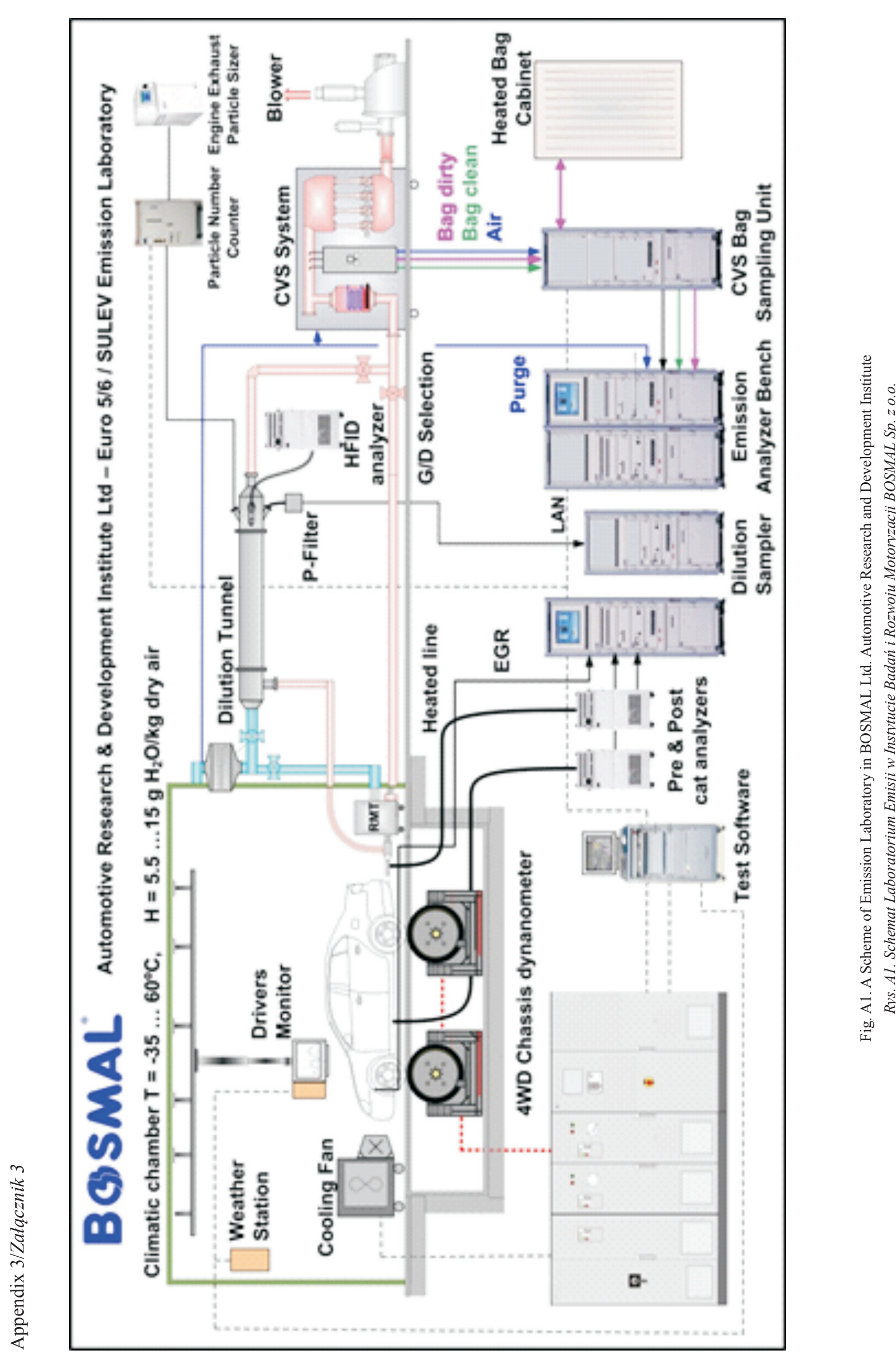
Appendix 1/Załacznik 1

Table 1. US Federal and California emission standards

Tabela 1. Amerykańskie federalne i kalifornijskie limity emisji cząstek statych

USA EPA Federal Emission Standards for PC\&LDV and LEV II/III CARB Emission Standards

\begin{tabular}{|c|c|c|c|c|c|c|c|}
\hline \multicolumn{8}{|c|}{ USA EPA Federal Emission Standards for PC\&LDV and LEV II/III CARB Emission Standards } \\
\hline \multirow{2}{*}{$\begin{array}{l}\text { Category:EPA Tier - Passenger } \\
\text { Cars and Light Duty Vehicles } \\
\text { CARB - LowEmission Vehicles }\end{array}$} & EPA:Tier II & EPA: Tier II & CARB: LEV II & CARB: LEV II & \multicolumn{3}{|c|}{ Planned CARB LEV III } \\
\hline & till 2009 & from 2009 & 2015-17 & 2015-17 & \multicolumn{2}{|c|}{$2017-21$} & $2025-28$ \\
\hline mileage [mi] & 120000 & 120000 & 50000 & 120000 & $\mathrm{n} / \mathrm{a}$ & $\mathrm{n} / \mathrm{a}$ & $\mathrm{n} / \mathrm{a}$ \\
\hline $\mathrm{PM}[\mathrm{mg} / \mathrm{km}]$ & \multicolumn{2}{|c|}{$0,0-12,4$ (US Tier 2, Bin $1 \ldots 8)$} & $\mathrm{n} / \mathrm{a}$ & 6.21 & 1.86 & & 0.62 \\
\hline
\end{tabular}

Appendix 2/Załacznik 2

Table 2. The European emission standards [25]

Tabela 2. Europejskie limity emisji czastek stałych [25]

\begin{tabular}{|c|c|c|c|c|c|c|c|c|c|c|}
\hline \multicolumn{11}{|c|}{ European emission standards } \\
\hline \multirow{2}{*}{\multicolumn{3}{|c|}{$\begin{array}{c}\text { Passenger Cars and Light Duty } \\
\text { Vehicles }\end{array}$}} & EU-1 & EU-2 & EU-3 & EU-4 & EU-5a & EU-5b & EU-6b & EU-6c \\
\hline & & & 1992 & 1996 & 2000 & 2005 & 2009 & 2011 & 2014 & 2017 \\
\hline \multirow{2}{*}{$\begin{array}{c}\text { DISI } \\
\text { Engines }\end{array}$} & $\mathrm{PM}$ & $\mathrm{mg} / \mathrm{km}$ & - & - & - & - & 5.0 & 4.5 & 4.5 & 4.5 \\
\hline & PN & $1 / \mathrm{km}$ & - & - & - & - & - & - & $6 \times 10^{12}$ & $6 \times 10^{11}$ \\
\hline \multirow{2}{*}{ CI Engines } & $\mathrm{PM}$ & $\mathrm{mg} / \mathrm{km}$ & 140 & 80 & 50 & 25 & 5.0 & 4.5 & 4.5 & 4.5 \\
\hline & PN & $1 / \mathrm{km}$ & - & - & - & - & - & $6 \times 10^{11}$ & $6 \times 10^{11}$ & $6 \times 10^{11}$ \\
\hline
\end{tabular}
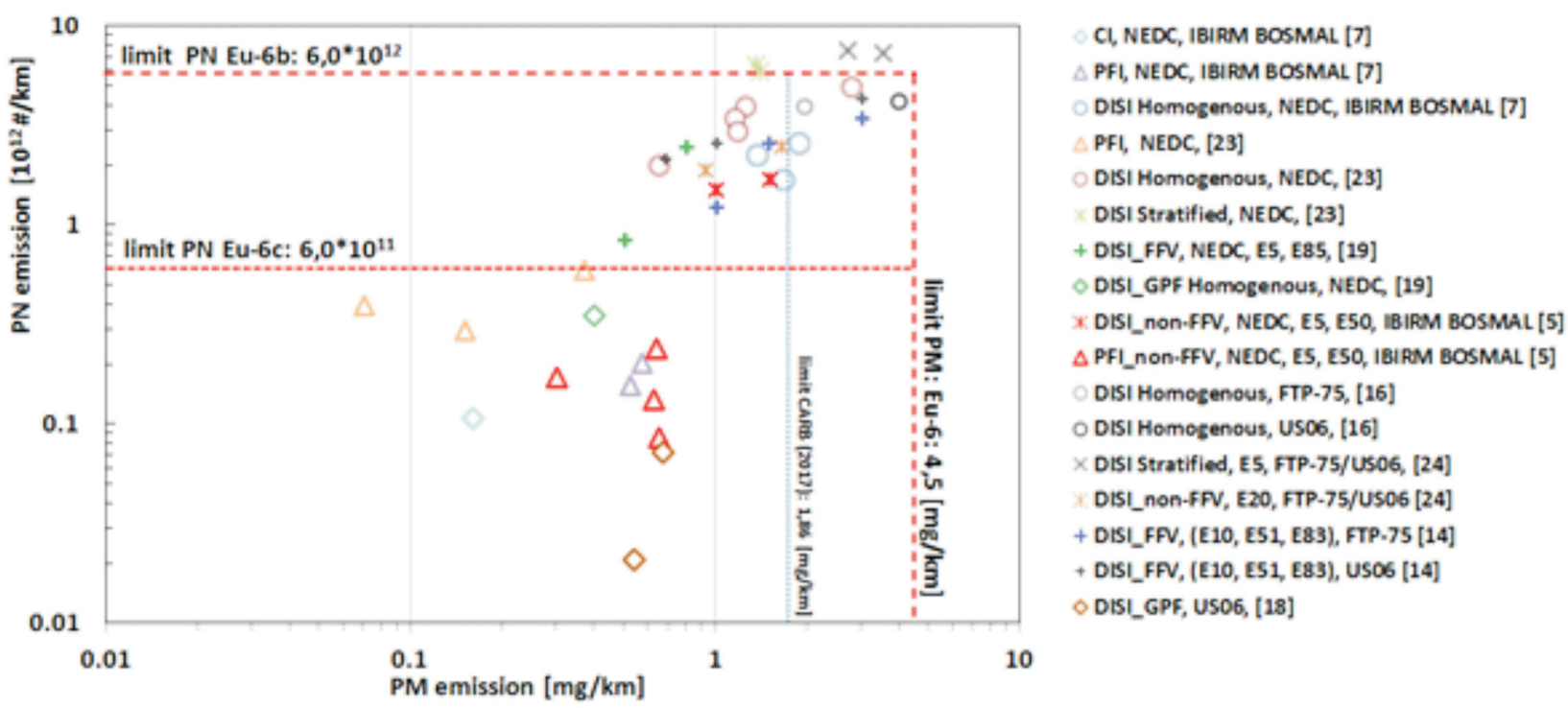

Fig. A2. Map of PM and PN results presented in the paper

Rys. A2. Mapa wyników emisji PM i PN dla przedstawionych wyników badań

Michał Olczyk, MEng. - Test Engineer in the Engine Research Department at BOSMAL Automotive Research \& Development Institute Ltd in Bielsko-Biała.

Mgr inż. Michat Olczyk - Samodzielny pracownik ds. badań w Zakładzie Badań Silników, Instytut Badań i Rozwoju Motoryzacji BOSMAL Sp. z o.o., Bielsko-Biata. e-mail: michal.olczyk@bosmal.com.pl

Bartosz Hejny, MEng. - Test Engineer in the Engine Research Department at BOSMAL Automotive Research \& Development Institute Ltd in Bielsko-Biała. Mgr inż. Bartosz Hejny - Samodzielny pracownik ds. badań w Zaktadzie Badań Silników, Instytut Badań i Rozwoju Motoryzacji BOSMAL Sp. z o.o., Bielsko-Biała. e-mail: bartosz.hejny@bosmal.com.pl

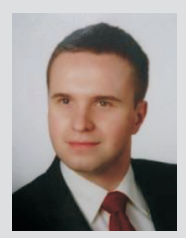

Piotr Bielaczyc, DEng. - Head of the Engine Research Department at BOSMAL Automotive Research \& Development Institute Ltd in Bielsko-Biała.

Dr inż. Piotr Bielaczyc - kierownik Zakladu Badań Silników, Instytut Badań i Rozwoju Motoryzacji BOSMAL Sp. z o.o., Bielsko-Biata.

e-mail:piotr.bielaczyc@bosmal.com.pl 